\title{
Roles of Nitrogen Deep Placement on Grain Yield, Nitrogen Use Efficiency, and Antioxidant Enzyme Activities in Mechanical Pot-Seedling Transplanting Rice
}

\author{
Lin Li ${ }^{1,2}$, Zheng Zhang ${ }^{1,2}$, Hua Tian ${ }^{1,2}$, Zhaowen Mo ${ }^{1,2}$, Umair Ashraf ${ }^{1,3}$, Meiyang Duan ${ }^{1,2}$, \\ Zaiman Wang ${ }^{4}$, Shuli Wang ${ }^{1,2}$, Xiangru Tang ${ }^{1,2, *(\mathbb{D})}$ and Shenggang Pan ${ }^{1,2, *}$ \\ 1 State Key Laboratory for Conservation and Utilization of Subtropical Agro-bioresources, College of \\ Agriculture, South China Agricultural University, Guangzhou 510642, China; scaulilin@126.com (L.L.); \\ scauzhangzheng@126.com (Z.Z.); tianhua@scau.edu.cn (H.T.); scaumozhw@126.com (Z.M.); \\ umairashraf2056@gmail.com (U.A.); meiyang@scau.edu.cn (M.D.); wangshuli@scau.edu.cn (S.W.) \\ 2 Scientific Observing and Experimental Station of Crop Cultivation in South China, Ministry of Agriculture \\ PR China, Guangzhou 510642, China \\ 3 Department of Botany, University of Education (Lahore), Faisalabad-Campus, \\ Faisalabad 38000, Punjab, Pakistan \\ 4 Key Laboratory of Key Technology for South Agricultural Machine and Equipment, Ministry of Education, \\ Guangzhou 510642, China; wangzaiman@scau.edu.cn \\ * Correspondence: tangxr@scau.edu.cn (X.T.); panshenggang@scau.edu.cn (S.P.)
}

Received: 2 August 2020; Accepted: 21 August 2020; Published: 25 August 2020

\begin{abstract}
Mechanical pot-seedling transplanting (PST) is an efficient transplanting method and deep nitrogen fertilization has the advantage of increasing nitrogen use efficiency. However, little information is available about the effect of PST when coupled with mechanized deep nitrogen (N) fertilization on grain yield, nitrogen use efficiency, and antioxidant enzyme activities in rice. A two-year field experiment was performed to evaluate the effect of PST coupled with deep N fertilization in both early seasons (March-July) of 2018 and 2019. All seedlings were transplanted by PST and three treatments were designed as follows. There was a mechanized deep placement of all fertilizer (MAF), broadcasting fertilizer (BF), no fertilizer (N0). MAF significantly increased grain yield by $52.7 \%$. Total nitrogen accumulation (TNA) was enhanced by $27.7 \%$, nitrogen partial factor productivity (NPFP) was enhanced by $51.4 \%$. nitrogen recovery efficiency (NRE) by $123.7 \%$, and nitrogen agronomic efficiency (NAE) was enhanced by 104.3\%, compared with BF treatment. Moreover, MAF significantly improved peroxidase (POD), catalase (CAT), and notably reduced the malonic dialdehyde (MDA) content for both rice cultivars, compared to BF. Hence, the result shows that mechanical pot-seedling transplanting coupled with nitrogen deep placement is an efficient method with the increase of grain yield and nitrogen use efficiency in rice cultivation in South China.
\end{abstract}

Keywords: deep N fertilization; peroxidase activity; catalase activity; rice cultivation

\section{Introduction}

Rice (Oryza sativa L.) is one of the world's major crops and it provides food for over three billion people $[1,2]$. China is the main country of rice production, with rice planting area and yield in the forefront of the world [2,3]. Therefore, increasing rice production is essential for population growth in China and the world [4,5]. Transplanted rice is the most traditional planting method. Moreover, the traditional fertilization method is manually surface broadcast [6]. This method is not suitable for the stable improvement in Chinese agricultural systems because of some serious problems such 
as labor scarcity and low profits [7]. Therefore, improving mechanization is the main way to solve this problem.

The mechanical pot-seedling transplanting (PST) is an innovative technology for transplanting rice seedlings in the paddy field. It has the advantage of precise row and hill spacing without injury to the rice plants [8]. The technique not only reduces planting costs but improves the quality of transplanting rice seedlings [9]. Mechanical pot-seedling transplanting can transplant seedlings without root injury. It expects to reduce the transplanting shock and maintain the root activity, resulting in increased nutrient absorption and consequently a vigorous initial growth [10]. However, the application of nitrogen fertilizer under the flooding condition can cause nitrogen fertilizer to be lost through ammonia volatilization and runoff, reducing the utilization efficiency of nitrogen fertilizer [11,12]. Thus, the seedlings transplanted by mechanical pot-seedling transplanting were unable to access the $\mathrm{N}$ resource, restricting their performance irrespective of enhanced root activity [4]. To solve this problem, much application of chemical fertilizer is one of the approaches, but it can lead to problems of lower nitrogen use efficiency (NUE) and environmental pollution $[11,13]$.

Alternative is the deep $\mathrm{N}$ fertilization in mechanical pot-seedling transplanting. Deep fertilizer application methods can maintain the nutrient and enhance nutrient use efficiency [14]. The nitrogen fertilization at about $5 \mathrm{~cm}$ depth notably improves the total above-ground biomass and grain yield, compared to the manual surface broadcast [15]. Moreover, deep fertilization could reduce the amount of fertilizer applications without reducing yield [16]. Deep fertilization is to bury the fertilizer near the rice root, which is beneficial for fertilizer absorption by rice root [17]. The appropriate fertilization depth could not only promote the growth of rice root but also improve the growth of rice plants in the early stage [18]. Some studies found that deep $\mathrm{N}$ fertilization could reduce $\mathrm{CH}_{4}$ emissions by $40 \%$ and NO emissions by $54 \%[19,20]$. Pan et al. [21] found that deep fertilization significantly increased peroxidase (POD) and catalase (CAT) in direct-seeded rice. Xu et al. [22] observed that ensuring the nutrient supply at the late stage of rice was conducive to improving antioxidant enzyme activities and photosynthetic performance of rice leaves. Moreover, Shu et al. [23] reported that mechanical deep fertilization could delay rice plan senescence by enhancing antioxidant enzyme activities and reducing the malonic dialdehyde (MDA) content in direct-seeded rice. Therefore, deep nitrogen fertilization is a feasible way to lessen environmental problems because of the excess fertilization in rice production.

Mechanical pot-seedling transplanting (PST) coupled with deep nitrogen fertilization is an emerging transplanting rice technology. However, little information is available about the effects of PST coupled with mechanized deep $\mathrm{N}$ fertilization on grain yield, nitrogen use efficiency, and antioxidant enzyme activities in rice. The aim of this study was to assess whether PST coupled with mechanized N deep fertilization could increase grain yield, nitrogen use efficiency, and antioxidant enzyme activities in rice.

\section{Materials and Methods}

\subsection{Mechanical Pot-Seedling Transplanting Machine}

A mechanical pot-seedling transplanting machine was developed by Changzhou YaMeiKe mechanical Co., Ltd. (Changzhou, China) (Figure 1). This method realized the synchronous operation of deep fertilization and transplanting seedlings and applied fertilizer quantitatively and fixed-point deep into the soil on the seedling side. 


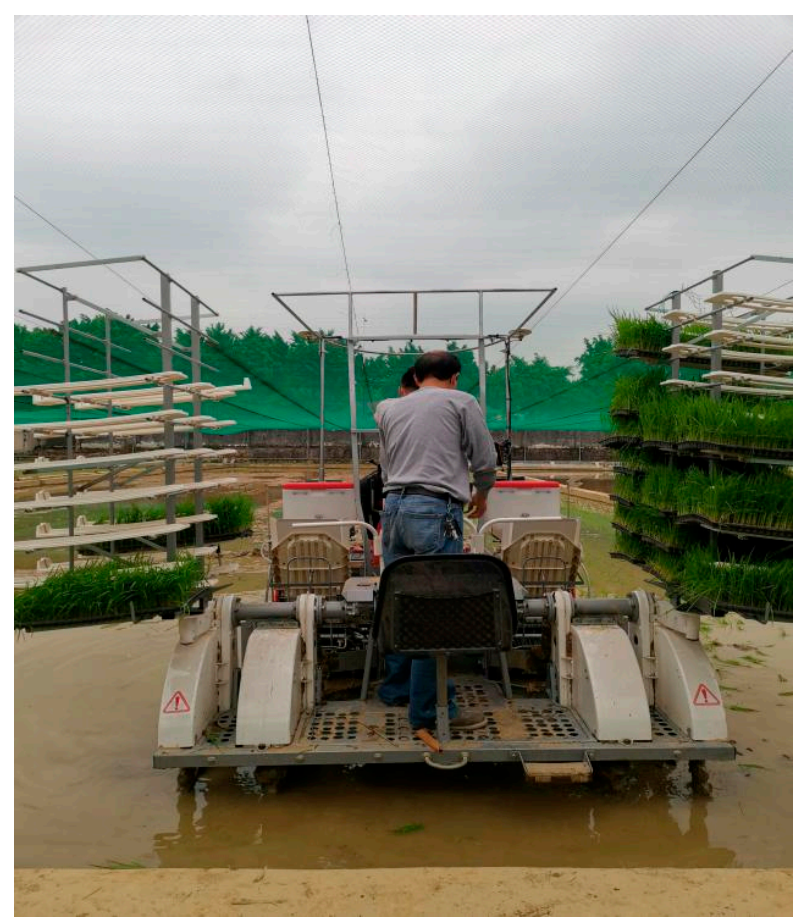

Figure 1. Pictorial view of mechanized transplanting rice machine coupled with $\mathrm{N}$ deep placement at the farm of South China Agricultural University, Guangzhou city, China.

\subsection{Experimental Treatments and Design}

Field experiments were conducted in early seasons of 2018 and 2019, respectively, at the Experimental Research Farm, College of Agriculture, South China Agricultural University, Guangzhou City, China $\left(23^{\circ} 13^{\prime} \mathrm{N}, 113^{\circ} 81^{\prime} \mathrm{E}\right.$, altitude $\left.11 \mathrm{~m}\right)$. The soil in the experimental field was sandy loam with $1010 \mathrm{mg} \mathrm{kg}^{-1}$ total $\mathrm{N}, 1080 \mathrm{mg} \mathrm{kg}^{-1}$ total $p, 20,230 \mathrm{mg} \mathrm{kg}^{-1}$ total $\mathrm{K}, 73 \mathrm{mg} \mathrm{kg}^{-1}$ available $p, 104 \mathrm{mg} \mathrm{kg}^{-1}$ available $\mathrm{K}$, and $21,560 \mathrm{mg} \mathrm{kg}^{-1}$ organic $\mathrm{C}$.

Two rice cultivars were Yuxiangyouzhan (YXYZ) and Wufengyou615 (WFY615), which are inbred and hybrid rice, respectively, and widely grown in the local area. Moreover, the two rice cultivars have growth periods of 118 and 115 days for both early seasons, respectively. Both field experiments were used in a completely randomized design with three replicates with a plot area of $132 \mathrm{~m}^{2}$ $(8 \mathrm{~m} \times 16.5 \mathrm{~m})$. The YaraMila compound fertilizer (total nitrogen contents $\mathrm{TN}=15 \%, \mathrm{~N}: \mathrm{P}_{2} \mathrm{O}_{5}: \mathrm{K}_{2} \mathrm{O}=$ 15\%:15\%:15\%) was used in our experiment, which was manufactured by YaraMila Fertilizer Company, China. The application rate was $150 \mathrm{~kg} \mathrm{~N} \mathrm{ha}^{-1}$ (pure N) for the fertilizer application treatment. All seedlings were transplanted by PST and three treatments were designed as follows. The mechanized deep $\mathrm{N}$ fertilization was a basal fertilizer in $10 \mathrm{~cm}$ soil depth (MAF) and fertilizers were broadcast manually on the soil surface two days before the transplanting as a basal fertilizer (BF). No fertilizer was applied during entire growth stage (N0). Water management strategies were adopted by local farmer's advice. Some chemical reagents such as herbicide, imidacloprid, tricyclazole, and carbendazim were adopted to prevent and control weeds, insects, and diseases.

\subsection{Yield and Its Components}

At maturity, rice grains were recorded from the harvested-area of $6 \mathrm{~m}^{2}$. In total, 20 rice plants were collected randomly for each treatment and the averaged values were calculated for the number of productive panicles per hill. Six hills of rice plants were taken to investigate yield components and the yield components measurement were determined according to Pan et al. [21]. To divide the filled seeds, all spikelets were submerged in tap water, apart from the rachis (by manual threshing). To calculate the total number of spikelets, we counted the spikelets in three representative subsamples 
of $30 \mathrm{~g}$. The average weight of half-filled spikelets was determined. Spikelets per panicle, grain-filling percentage, and 1000-grain-weight were also calculated from sampled plants and averaged.

\subsection{Total Above-Ground Biomass (TAB) and Leaf Area Index (LAI) at Different Growth Stages}

According to the average number of tillers in the plot, six plants were taken in the plot at all critical growth stages including mid-tillering (MT), panicle initiation (PI), heading stage (HS), and the maturity stage (MS). LAI and TAB were determined according to Pan et al. [21]. The soil on the rice plants were washed thoroughly. Then, leaf sheaths plus stems, leaves, and spikes were separated from the plant after the heading stage. The leaf area for all green leaf blades was measured with the Li-Cor area meter (Li Cor Model 3100, Lincoln, NE, USA) and the leaf area per $\mathrm{m}^{2}$ (leaf area index, LAI) was then calculated. The separated part of the rice plants was oven-dried at $70{ }^{\circ} \mathrm{C}$ to constant weight and then the above-ground biomass was calculated.

\subsection{Nitrogen Use Efficiency}

Six plants were collected from each treatment in the physiological maturity stage. They were then divided into leaves, stems with leaf sheath, and grains. They were finally dried at $70{ }^{\circ} \mathrm{C}$ until constant weight, then stored to analyze the total $\mathrm{N}$ contents. Plant samples $(0.2 \mathrm{~g})$ were digested using the Kjeldhal method to analyze ammonia concentrations via an Alliance-Futura NP analyzer (Alliance Instruments, France) and then the $\mathrm{N}$ content was measured. The nitrogen use efficiency including nitrogen recovery efficiency (NRE), nitrogen agronomic use efficiency (NAE), nitrogen partial factor productivity (NPFP), nitrogen harvest index (NHI), and nitrogen grain production efficiency (NGPE) were evaluated by the formulae below:

1. $\quad \mathrm{NRE}=(\mathrm{Nup}-\mathrm{N} 0$ up $) / \mathrm{FN}$

2. $\mathrm{NAE}=(\mathrm{GY}-\mathrm{GY} 0) / \mathrm{FN}$

3. $\mathrm{NPFP}=\mathrm{GY} / \mathrm{FN}$

4. $\quad$ NGPE $=$ GY/Nup

5. $\quad \mathrm{NHI}=\mathrm{Ng} / \mathrm{Nup}$

where N0 up and GY0 represented the total nitrogen uptake of above-ground plant parts and grain yields in the N0 plot, respectively. Nup and GY are the total nitrogen uptake of above-ground plant parts and grain yields in other $\mathrm{N}$-fertilized plots, respectively. $\mathrm{FN}$ is the applied $\mathrm{N}$ fertilizer rate; $\mathrm{Ng}$ is the total nitrogen uptake in grain.

\subsection{Determination of Antioxidant Enzyme Activities}

About 25 leaves from each treatment were collected during the MT, PI, and HS stage. All samples were stored in $-80{ }^{\circ} \mathrm{C}$ for enzyme activity determination i.e., peroxidase (POD), catalase (CAT), and malonic dialdehyde (MDA). POD and MDA were determined by the method established by Pan et al. [24]. Fresh leaf segments $(<2 \mathrm{~mm}, 0.25 \mathrm{~g})$ were homogenized in an ice bath in $5 \mathrm{~mL}$ of $50 \mathrm{~mm}$ borate buffer ( $\mathrm{pH}$ 8.7) containing $5.0 \mathrm{~mm}$ sodium hydrogen sulfite and $0.1 \mathrm{~g}$ polyvinylpyrrolidone (PVP). The homogenate was centrifuged at $9000 \times \mathrm{g}$ for $15 \mathrm{~min}$ at $4{ }^{\circ} \mathrm{C}$. The supernatant was used as enzyme extract. POD activity was assayed by adding $0.1 \mathrm{~mL}$ of the enzyme extract to a substrate mixture containing acetate buffer $\left(0.1 \mathrm{~mol} \mathrm{~L}^{-1}, \mathrm{pH} 5.4\right)$, ortho-dianisidine $(0.25 \%$ in ethyl alcohol) and $0.1 \mathrm{~mL} 0.8 \% \mathrm{H}_{2} \mathrm{O}_{2}$ was added to $0.1 \mathrm{~mL}$ of the enzyme extract. Absorbance change of the brown guaiacol at $460 \mathrm{~nm}$ was recorded for calculating POD activity. One POD unit of enzyme activity was defined as the absorbance increase because of guaiacol oxidation by 1-unit $\min ^{-1}\left(\mathrm{U} \mathrm{g}^{-1} \mathrm{FW} \mathrm{min}{ }^{-1}\right)$. Leaf samples $(0.5 \mathrm{~g})$ were homogenized in $5 \mathrm{~mL}$ of $5 \%$ trichloroacetic acid. The homogenate was centrifuged at $4000 \times \mathrm{g}$ for $10 \mathrm{~min}$ at $25^{\circ} \mathrm{C}$ and $3 \mathrm{~mL}$ of 2-thiobarbituric acid in $20 \%$ trichloroacetic acid was added to a $2 \mathrm{~mL}$ aliquot of the supernatant. The mixture was heated at $98{ }^{\circ} \mathrm{C}$ for $10 \mathrm{~min}$ and cooled rapidly in an ice bath. After centrifugation at $4000 \times \mathrm{g}$ for $10 \mathrm{~min}$, the absorbance was recorded at $532 \mathrm{~nm}$. Measurements were corrected for non-specific turbidity by subtracting the 
absorbance at $600 \mathrm{~nm}$. MDA concentration was determined by the extinction coefficient MDA ( $\varepsilon=$ $155 \mu \mathrm{m} \mathrm{cm}^{-1}$ ). CAT activities were determined according to Dhindsa et al. [25]. The $3 \mathrm{~mL}$ reaction mixture contained $50 \mathrm{mM}$ phosphate buffer, $\mathrm{pH}$ 7.0, $15 \mathrm{mM}$ hydrogen peroxide, and $25 \mu \mathrm{L}$ enzyme extract. The decrease in hydrogen peroxide was followed as a decline in A240 using a Perkin-Elmer double-beam spectrophotometer connected to a recorder. The activity was expressed in units where one unit of catalase converts one $\mu$ mole of hydrogen peroxide per minute.

\subsection{Data Analysis}

The experimental data were analyzed using DPS3.11 (Data Processing System for Practical Statistics, Hangzhou, China). In the ANOVA model, the single effect of treatment, cultivar, year, and the interaction effect were fixed, while the replication effect in year was random. The differences amongst means of the experimental treatments were separated using the least significant difference (LSD) at 0.05 probability level (ANOVA). All figures were drawn with Origin 9.0.

\section{Results}

\subsection{Grain Yield and Its Components}

The grain yield and its components varied with different $\mathrm{N}$ fertilizer applications for both rice cultivars (Table 1). The highest grain yield for MAF treatment was found for the BF and N0 treatments in both years. Mean grain yields of both rice cultivars under MAF were $8.4 \mathrm{t} \mathrm{ha}^{-1}$, which was $52.7 \%$ higher than the BF treatment. Regarding yield components, deep placement produced the highest number of productive panicles $\mathrm{ha}^{-1}$ and spikelet per panicle, which was $272.9 \times 10^{4}$ and 189.7, respectively. No significance was found between BF and N0 treatment in the 1000-grain-weight and grain filling. Significant differences were found in the number of productive panicles, spikelets per panicle, 1000-grain-weight, and grain yield between nitrogen treatments. Both rice cultivars differed significantly in 1000-grain-weight.

Table 1. Effects of mechanical deep placement of nitrogen fertilizer on average grain yield and its components for both rice cultivars in two-year (2018 and 2019).

\begin{tabular}{|c|c|c|c|c|c|}
\hline Treatments & $\begin{array}{l}\text { Productive } \\
\text { Panicle } \\
\left(10^{4} \mathrm{Ha}^{-1}\right)\end{array}$ & $\begin{array}{l}\text { Spikelet } \\
\text { per } \\
\text { Panicle }\end{array}$ & $\begin{array}{l}\text { Grain } \\
\text { Filling } \\
(\%)\end{array}$ & $\begin{array}{l}\text { 1000-Grain- } \\
\text { Weight } \\
\text { (G) }\end{array}$ & $\begin{array}{c}\text { Harvested } \\
\text { Yield } \\
\left(\mathrm{T} \mathrm{Ha}^{-1}\right)\end{array}$ \\
\hline N0 & $151.4 \mathrm{~b}$ & $150.3 \mathrm{~b}$ & 80.9 & $20.1 \mathrm{~b}$ & $3.9 \mathrm{c}$ \\
\hline MAF & $272.9 \mathrm{a}$ & 189.7 a & 82.7 & $22.2 \mathrm{a}$ & $8.4 \mathrm{a}$ \\
\hline $\mathrm{BF}$ & $185.3 \mathrm{~b}$ & $163.3 \mathrm{~b}$ & 81.6 & $21.1 \mathrm{~b}$ & $5.5 \mathrm{~b}$ \\
\hline \multicolumn{6}{|l|}{ Anova } \\
\hline Cultivar (C) & ns & ns & ns & $* *$ & ns \\
\hline Nitrogen (N) & $* *$ & $*$ & ns & $* *$ & $* *$ \\
\hline $\mathrm{N} \times \mathrm{C}$ & ns & ns & ns & ns & ns \\
\hline
\end{tabular}

MAF: mechanized deep placement of all fertilizer; BF: broadcasting fertilizer; N0: no fertilizer. Average values followed by different letter represent LSD significant differences at $p<0.05 .{ }^{* *}:(p<0.01)$; ${ }^{*}:(p<0.05)$; ns: not significant variance.

\subsection{Nitrogen Use Efficiency}

The TNA, NGPE, NHI, NAE, NPFP, and NRE varied with different $\mathrm{N}$ fertilizer application in both rice cultivars (Table 2). In two-years, the $\mathrm{N}$ fertilizer application (MAF and $\mathrm{BF}$ ) treatments significantly increased TNA relative to N0 treatment. Moreover, MAF treatment significantly increased TNA compared to BF treatment. The TNA of both rice cultivars for MAF was $173.6 \mathrm{~kg} \mathrm{ha}^{-1}$, which was $27.7 \%$ higher than the BF treatment, respectively. NGPE was highest in MAF, followed by BF, and the lowest was the N0 treatment. MAF showed the maximum NRE and NAE, while the BF had the lowest value for NRE and NRE among all treatments, respectively. Furthermore, a significant difference was 
found between MAF and BF. The NPFP of both rice cultivars for MAF was $54.2 \mathrm{~kg} \mathrm{~kg}^{-1}$, which was $51.4 \%$ higher than that in the BF treatment, respectively. Moreover, no remarkable difference among all treatment was found in NHI. There were notable differences in TNA, NGPE, NPFP, NAE, and NRE between nitrogen treatments. Moreover, the $\mathrm{N} \times \mathrm{C}$ (Nitrogen $\times$ Cultivar) factor interactions also had an obvious impact on TNA and NHI (Table 2).

Table 2. Effects of mechanical deep placement of nitrogen fertilizer on average nitrogen use efficiency for both rice cultivars in two-year (2018 and 2019).

\begin{tabular}{|c|c|c|c|c|c|c|}
\hline Treatments & $\begin{array}{c}\text { TNA } \\
\left(\mathrm{kg} \mathrm{ha}^{-1}\right)\end{array}$ & $\begin{array}{c}\text { NGPE } \\
\left(\mathrm{kg} \mathrm{kg}^{-1}\right)\end{array}$ & $\begin{array}{c}\text { NPFP } \\
\left(\mathrm{kg} \mathrm{kg}^{-1}\right)\end{array}$ & NHI & NRE (\%) & $\begin{array}{c}\text { NAE } \\
\left(\mathrm{kg} \mathrm{kg}^{-1}\right)\end{array}$ \\
\hline N0 & $100.6 \mathrm{c}$ & $39.2 \mathrm{~b}$ & $26.8 \mathrm{c}$ & 53.2 & & \\
\hline MAF & $173.6 \mathrm{a}$ & $46.6 \mathrm{a}$ & $54.2 \mathrm{a}$ & 54.3 & $46.8 \mathrm{a}$ & $22.6 \mathrm{a}$ \\
\hline BF & $135.9 \mathrm{~b}$ & $41.4 \mathrm{~b}$ & $35.8 \mathrm{~b}$ & 50.8 & $22.9 \mathrm{~b}$ & $10.1 \mathrm{~b}$ \\
\hline \multicolumn{7}{|l|}{ Anova } \\
\hline Cultivar(C) & $* *$ & ns & $*$ & $*$ & ns & $*$ \\
\hline Nitrogen(N) & $* *$ & $*$ & $* *$ & ns & $* *$ & $* *$ \\
\hline $\mathrm{N} \times \mathrm{C}$ & $* *$ & ns & ns & $* *$ & ns & ns \\
\hline
\end{tabular}

Average values followed by different letter represent LSD significant differences at $p<0.05 .^{* *}:(p<0.01) ;{ }^{*}:(p<0.05)$; ns: not significant variance. TNA: Total nitrogen accumulation; NAE: N agronomic efficiency, NRE: N recovery efficiency, NGPE: N grain production efficiency; NHI: N harvest index, NPFP: nitrogen partial factor productivity.

\subsection{Total Aboveground Biomass (TAB) and Leaf Area Index (LAI) at Different Growth Stage}

The $\mathrm{N}$ fertilizer application remarkably affected the LAI for both rice cultivars (Figure 2). For example, during the MT stage, the LAI for BF and MAF treatments were significantly higher than N0, but no significant difference was found between MAF and BF. At the PI and HS stages, MAF was significantly larger for LAI, especially when compared to N0 and BF. The result manifested that deep placement of the $\mathrm{N}$ application could modulate a sustainable longer growth period than surface broadcasting.
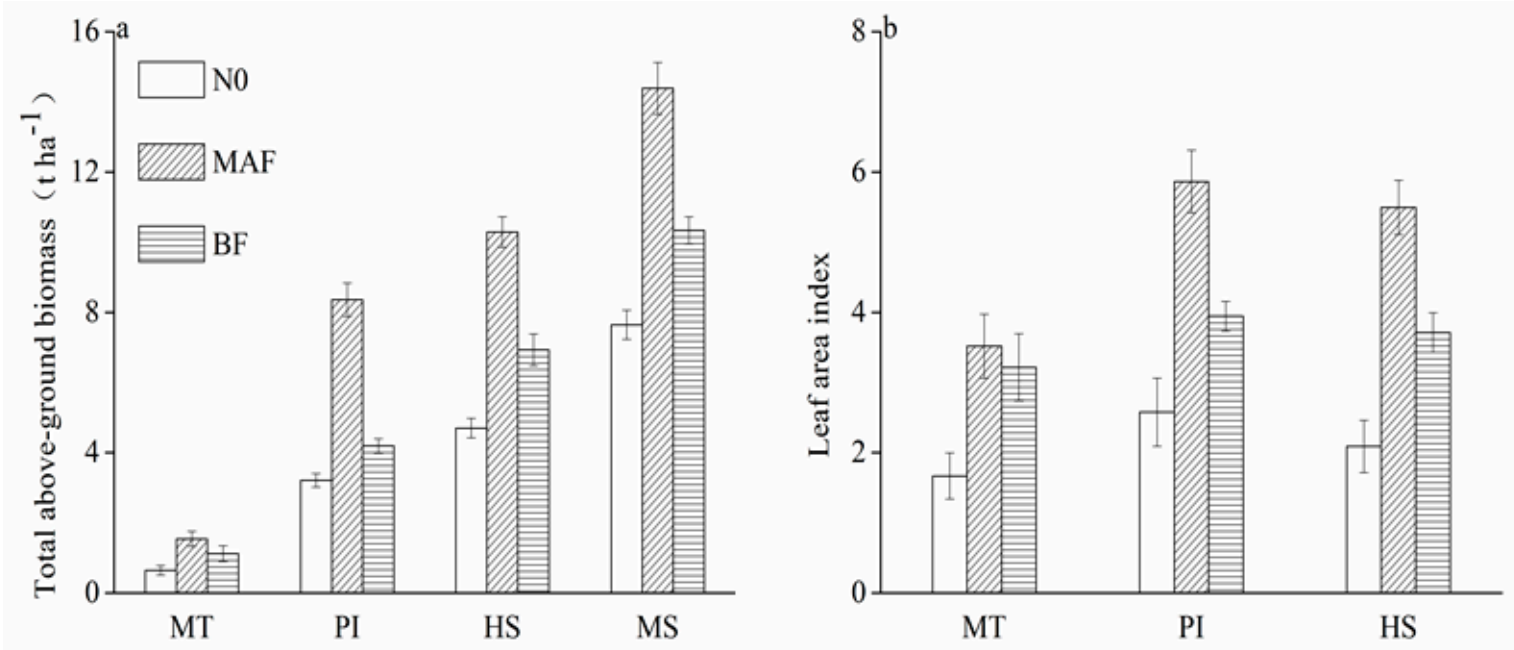

Figure 2. Effects of mechanical deep placement of nitrogen fertilizer on average for the total above-ground biomass and leaf area index for both rice cultivars (2018 and 2019). (a): total above-ground biomass, (b): leaf area index. MT: Mid-tillering stage; PI: Panicle initiation stage; HS: Heading stage; MS: Maturity stage.

The $\mathrm{N}$ fertilizer application remarkably affected the TAB for both rice cultivars (Figure 2). For example, at the MT stage, the TAB for BF and MAF treatments were significantly higher than N0. There were no significant differences between MAF and BF, and the TAB for MAF was higher than BF. At the HS and MS stages, N fertilizer application (MAF and BF) treatments remarkably increased TBA, 
especially when compared to the N0 treatment. Moreover, there were remarkable differences between MAF and BF treatments. In the whole growth period, a similar trend for TAB of both rice cultivars was observed.

\subsection{Determination of Antioxidant Enzymatic Activity}

\subsubsection{POD Activity}

The POD activity in the leaves at all critical growth stages including the MT, PI, and HS stages were shown in Figure 3. At the MT stage, the highest POD activities were observed in the MAF treatment. However, the POD activity of the BF treatment was higher than the N0 treatment while lower than the MAF treatment. At the PI stage, MAF treatment significantly improved POD activity, especially when compared to the BF treatment. However, the POD activity did not differ significantly between $\mathrm{BF}$ and $\mathrm{N} 0$ treatment. A significant difference was found among all treatments at the HS stage. In the whole growth period, the similar trend for POD activity of both rice cultivars was observed.
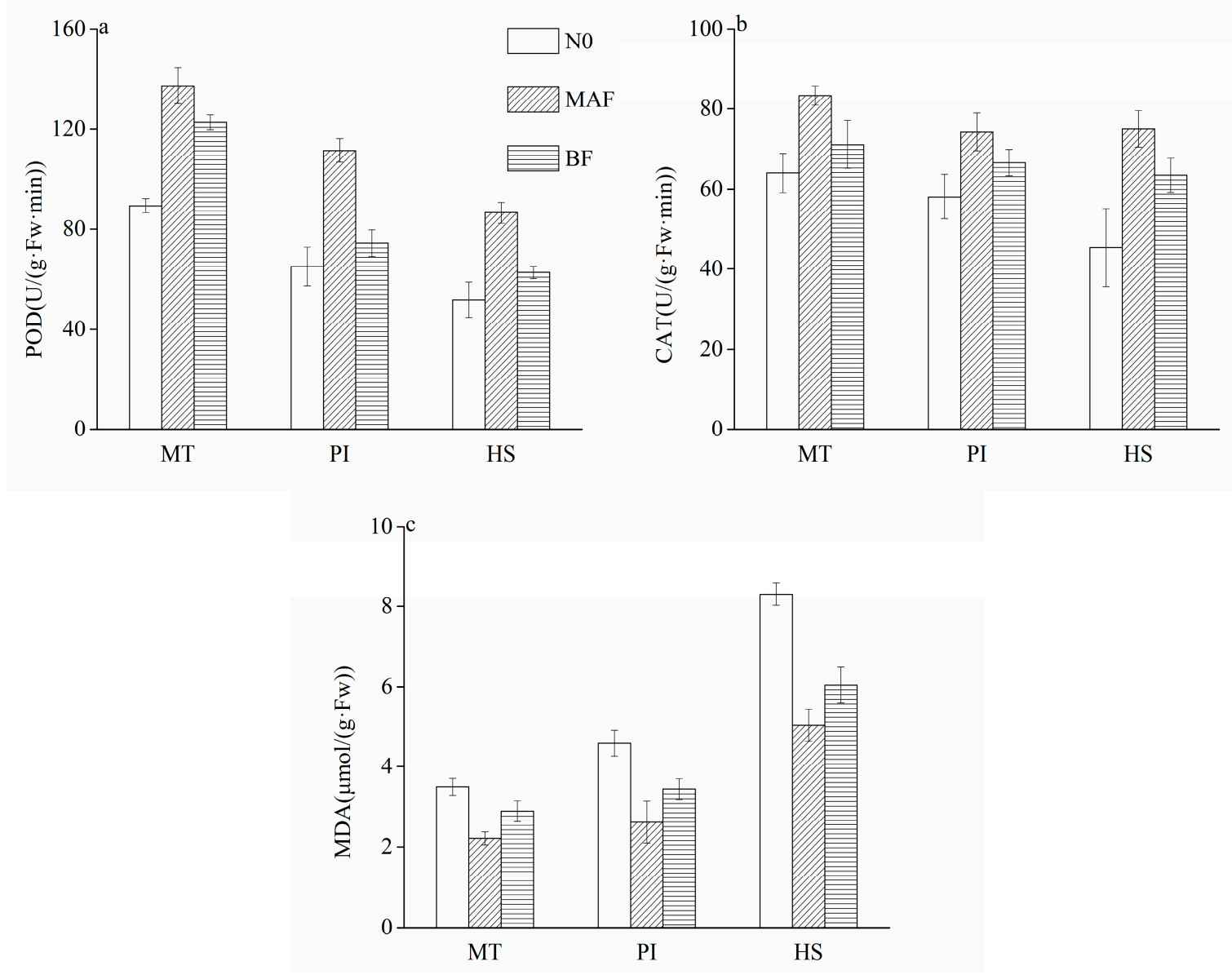

Figure 3. Effects of mechanical deep placement of nitrogen fertilizer on average for POD, CAT activity, and MDA content for both rice cultivars (2018 and 2019). (a): POD, (b): CAT, (c): MDA.

\subsubsection{CAT Activity}

The CAT activity in the leaves at all critical growth stages including the MT, PI, and HS stages were shown in Figure 3. There were significant differences in CAT activity found between the MAF and BF treatments at the MT stage. However, the BF and N0 treatments did not differ significantly. A significant difference of CAT activity was found between MAF and N0 treatment at the PI stage. At the HS stage, the highest CAT activities were observed in the MAF treatment over two years. 
However, CAT activity was higher in the BF treatment than the N0 treatment, while remaining lower than MAF treatment. Furthermore, a significant difference was found among all treatments.

\subsubsection{MDA Content}

The MDA content in the leaves at all critical growth stages including the MT, PI, and HS stages were shown in Figure 3. At the MT stage, the lowest MDA contents for both rice cultivars over two years were observed in the MAF treatment. However, the MDA content was higher in the BF treatment than the MAF treatment, while remaining lower than the N0 treatment. At the PI stage, compared to the N0 treatment, the BF and MAF treatments could significantly decrease MDA content. Marginal differences in MDA content was found between the MAF and BF treatments. Significant differences of MDA content were found among all treatments at the HS stage.

\subsection{Correlation Analysis}

The relationship among grain yield and its components TAB, TNA, LAI, and antioxidant enzyme activities for both rice cultivars over two years (Table 3). The variation of $\mathrm{N}$ treatment was focused on in the correlation analysis. Rice yield was significantly and positively correlated with the number of productive panicles ha ${ }^{-1}$, spikelet per panicle, TAB, LAI, and antioxidant enzyme activities, including POD and CAT activities. The spikelet per panicle also significantly correlated with LAI, TAB, and MDA content. Furthermore, TAB at the maturity stage and LAI at the HS stage significantly correlated with antioxidant enzyme activities and TNA.

Table 3. Relationship among grain yield, and its components, TAB, TNA, LAI, and antioxidant enzyme activities for both rice cultivars (2018 and 2019).

\begin{tabular}{|c|c|c|c|c|c|c|c|c|c|c|}
\hline Parameter & $\begin{array}{l}\text { Productive } \\
\text { Panicle }\end{array}$ & $\begin{array}{c}\text { Spikelet } \\
\text { per } \\
\text { Panicle }\end{array}$ & $\begin{array}{l}\text { Grain } \\
\text { Filling }\end{array}$ & $\begin{array}{l}\text { 1000-Grain } \\
\text {-Weigh (G) }\end{array}$ & LAI & ТАВ & POD & CAT & MDA & TNA \\
\hline $\begin{array}{l}\text { Productive } \\
\text { panicle }\end{array}$ & & & & & & & & & & \\
\hline $\begin{array}{l}\text { Spikelet } \\
\text { per panicle }\end{array}$ & 0.28 & & & & & & & & & \\
\hline $\begin{array}{l}\text { Grain } \\
\text { filling }\end{array}$ & -0.03 & -0.18 & & & & & & & & \\
\hline $\begin{array}{l}\text { 1000-grain- } \\
\text { weight(g) }\end{array}$ & 0.37 * & 0.18 & 0.33 * & & & & & & & \\
\hline LAI & $0.53^{* *}$ & $0.47^{* *}$ & 0.20 & $0.52^{* *}$ & & & & & & \\
\hline TAB & $0.68^{* *}$ & $0.44^{* *}$ & -0.06 & $0.51 * *$ & $0.85^{* *}$ & & & & & \\
\hline $\begin{array}{l}\text { POD } \\
\text { activity }\end{array}$ & $0.55^{* *}$ & 0.27 & $0.46^{* *}$ & $0.45^{* *}$ & $0.76^{* *}$ & $0.60^{* *}$ & & & & \\
\hline $\begin{array}{l}\text { CAT } \\
\text { activity }\end{array}$ & $0.49^{* *}$ & $0.51 * *$ & $-0.58^{* *}$ & 0.03 & $0.47^{* *}$ & 0.60 ** & 0.28 & & & \\
\hline $\begin{array}{c}\text { MDA } \\
\text { content }\end{array}$ & $-0.48^{* *}$ & $-0.44^{* *}$ & $0.54^{* *}$ & $-0.43^{* *}$ & $-0.52 * *$ & $-0.70^{* *}$ & -0.18 & $-0.74^{* *}$ & & \\
\hline TNA & $0.65^{* *}$ & 0.62 & -0.03 & $0.41 *$ & $0.74^{* *}$ & $0.71^{* *}$ & $0.62^{* *}$ & $0.52 * *$ & $-0.56^{* *}$ & \\
\hline Yield & $0.73^{* *}$ & 0.39 & -0.06 & $0.44^{* *}$ & $0.75 * *$ & $0.79 * *$ & $0.68^{* *}$ & $0.62 * *$ & $-0.61^{* *}$ & $0.79 * *$ \\
\hline
\end{tabular}

LAI: Leaf area index at HS stage; TAB: Total above-ground biomass at MS stage; POD: Peroxidase; CAT: Catalase, MDA: malonic dialdehyde at HS stage, TNA: Total nitrogen accumulation at MS stage. The same as below. ${ }^{* *}:(p<0.01) ; *:(p<0.05)$

\section{Discussion}

\subsection{Grain Yield and Its Components}

Compared with broadcasting fertilizer treatment (BF), mechanized deep placement of all fertilizers at once (MAF) significantly enhanced the grain yields in mechanical pot-seedling transplanting (PST). The highest yields of MAF treatment for both rice cultivars were mainly due to the number of productive panicles ha ${ }^{-1}$ and spikelet per panicle, which was in agreement with Bandaogo et al. [26]. Moreover, yield increase via a mechanized deep placement in PST was 52.7\% for both rice cultivars. The increase was far larger than in previous studies on mechanized deep placement in mechanical carpet-seedling transplanting (6.3-11.6\%) [15], suggesting that the mechanized deep placement method 
could be more effective under PST conditions than non-PST conditions. Moreover, Pan et al. [21] found that deep fertilization remarkably improved spikelet number per panicle in direct-seeded rice compared to manual surface broadcast fertilizers. Tracing it to the cause, the PST was used in our experiment, which opened a fassula and then uniformly placed the $\mathrm{N}$ fertilizer at $10 \mathrm{~cm}$ depth. Finally, the fassula was covered by this applicator immediately. This method provided a continuous nitrogen supply for rice growth and the $\mathrm{NH}_{4}{ }^{+}$absorbed by the root system remained in the soil for a longer period of time, thus promoting the growth of rice plants throughout the growth period and thereby increasing the nitrogen absorption and grain yield $[27,28]$. Deep placement fertilizer also maintained higher antioxidant enzyme activities at the heading stage, which was one of the reasons for the higher grain yield.

Compared with BF treatment, MAF significantly enhanced the leaf area index (LAI) and total above-ground biomass (TAB) at the PI and HS stages in PST. The main reason for this was that MAF treatment promoted rice growth in the middle and late stages by reducing nutrition loss. Broadcasting fertilizers did not meet this demand and led to insufficient nutrient supply. Moreover, LAI and TAB increased by mechanized deep placement in PST, reaching $58.5 \%$ and $40.2 \%$ for both rice cultivars, respectively. The increase was larger than in previous studies on mechanized deep placement in mechanical carpet-seedling transplanting (36.1-38.9\% and 8.7-10.6\%) [15,29]. In addition, a larger TAB was beneficial to the transportation of dry matter to the panicle, leading to more spikelet per panicle and 1000-grain-weight of rice, so as to improve the yield of rice. Our results showed that TAB at the MS stage remarkably correlated with LAI at the HS stage, and both of them were positively related to grain yield. The result indicated that MAF had some superiority in larger LAI and TAB, which thus resulted in a higher grain yield.

\subsection{Nitrogen Use Efficiency and Antioxidant Enzyme Activities}

We discovered that MAF led to a substantial increase in total $\mathrm{N}$ accumulation (TNA), $\mathrm{N}$ recovery efficiency (NRE), and agronomic efficiency (NAE) compared to BF treatment. Moreover, NAE and NRE increase by mechanized deep placement in PST was $104.3 \%$ and $123.7 \%$ for both rice cultivars, respectively. The increase was far larger than in previous studies on mechanized deep placement in mechanical carpet-seedling transplanting (17.9-43.1\% and 19.6-37.4\%), suggesting that the mechanized deep placement method could be more effective to improve NRE and NAE under PST conditions than non-PST conditions $[29,30]$. Some researchers have showed that deep fertilization could improve NUE by reducing nitrogen loss and prolonging the duration of fertilizer, which was compared with surface broadcasting [31,32]. Previous results also found that the deep $\mathrm{N}$ fertilization could reduce urease activity by increasing $\mathrm{NH}_{4}{ }^{+}$concentration in soil depth, thereby reducing $\mathrm{NH}_{4}{ }^{+}$concentration in flood water [33,34]. The reason was that the deep nitrogen fertilizer in the anaerobic soil layer caused the $\mathrm{NH}_{4}{ }^{+}$to move slowly from the depth to soil surface, thereby the $\mathrm{NH}_{4}{ }^{+}$content in the flood was low. Moreover, the decrease of $\mathrm{N}$ concentration in the flood reduced the loss of $\mathrm{N}$ through runoff, ammonia volatilization, and denitrification, thus improving the NUE. Deep placement of fertilizers was a concentrated application of fertilizer near the roots of rice, which was conducive to the absorption of roots and improved the NUE $[18,35]$. We also found that TNA content was significantly related to grain yield and antioxidant enzyme activities in a positive correlation, because the higher antioxidant enzyme activity at the full heading stage was decisive to the transfer of nutrients to grains, and increased the accumulation of nitrogen in grains, thus increasing the NAE and NRE of rice plants.

Our results showed that MAF notably increased antioxidant enzyme activities including POD and CAT and reduced the MDA content of both rice cultivars. Some reports have showed that the appropriate application of nitrogen fertilizer could maintain high antioxidant enzyme activities at the MS stage, which would be beneficial when delaying the senescence of functional leaves of rice [36,37]. The reason was that the deep application of fertilizer could fulfill nutrient requirements of rice growth and development in time, providing sufficient energy for the antioxidant enzyme activities of the plant, enhancing the activity of the plant leaf protection enzyme system, accelerating the scavenging of 
free radicals, and reducing membrane lipid peroxidation and the MDA content in the rice plant [38]. Moreover, the rice plant had a stronger root system and longer green leaf duration under deep $\mathrm{N}$ fertilization [4]. We also found a significant positive correlation between POD and CAT activities and grain yield. $\mathrm{N}$-fertilized plants need such effective antioxidant machinery to cope with excessive reactive oxygen species production. In this way, it can delay the senescence of leaves in the late growth stage $[23,38]$. Therefore, maintaining high POD and CAT activities at the HS stage was conducive to a higher rice yield.

\section{Conclusions}

Compared to broadcasting fertilizer treatment, mechanized deep $\mathrm{N}$ fertilization enhanced rice growth under mechanical pot-seedling transplanting (PST) in terms of leaf area index and total above-ground biomass. Mechanized deep N fertilization also improved the grain yield, nitrogen use efficiency, and antioxidant enzyme activities in PST. Therefore, mechanized deep fertilization in mechanical pot-seedling transplanting should be recommended in actual production.

Author Contributions: Conceptualization, S.P. and X.T.; Methodology, S.P. and X.T.; Data curation, H.T., Z.W., M.D., and S.W.; Formal analysis, L.L., H.T., Z.Z., and M.D.; Project administration, S.W., Z.W., and Z.Z.; Supervision, L.L., H.T., S.P., and X.T.; Validation, L.L., H.T., Z.M., M.D, and U.A.; Writing一original draft, L.L., H.T., Z.M., and M.D.; Writing—review and editing, L.L., H.T., Z.M., M.D., U.A., Z.W., S.P., and X.T. All authors have read and agreed to the published version of the manuscript.

Funding: The research was supported by Key-Area Research and Development Program of Guangdong Province (No.2019 B020221003) and National Natural Science Foundation of China (31471442).

Acknowledgments: We thank Leilei Kong who provided the rice cultivars. The research was supported by Key-Area Research and Development Program of Guangdong Province (No. 2019 B020221003) and National Natural Science Foundation of China (31471442).

Conflicts of Interest: The authors declare no conflict of interest.

\section{References}

1. Liu, K.; Deng, J.; Lu, J.; Wang, X.; Lu, B.; Tian, X.; Zhang, Y. High Nitrogen Levels Alleviate Yield Loss of Super Hybrid Rice Caused by High Temperatures During the Flowering Stage. Front. Plant Sci. 2019, $10,357$. [CrossRef] [PubMed]

2. He, A.; Wang, W.; Jiang, G.; Sun, H.; Jiang, M.; Man, J.; Cui, K.; Huang, J.; Peng, S.; Nie, L. Source-sink regulation and its effects on the regeneration ability of ratoon rice. Field Crop. Res. 2019, 236, 155-164. [CrossRef]

3. Kong, L.; Ashraf, U.; Cheng, S.; Rao, G.; Mo, Z.; Tian, H.; Pan, S.; Tang, X. Short-term water management at early filling stage improves early-season rice performance under high temperature stress in South China. Eur. J. Agron. 2017, 90, 117-126. [CrossRef]

4. Chen, Y.; Fan, P.; Mo, Z.; Kong, L.; Tian, H.; Duan, M.; Li, L.; Wu, L.; Wang, Z.; Tang, X.; et al. Deep Placement of Nitrogen Fertilizer Affects Grain Yield, Nitrogen Recovery Efficiency, and Root Characteristics in Direct-Seeded Rice in South China. J. Plant Growth Regul. 2020, 2, 1-9. [CrossRef]

5. Ashraf, U.; Hussain, S.; Akbar, N.; Anjum, S.A.; Hassan, W.; Tang, X. Water management regimes alter Pb uptake and translocation in fragrant rice. Ecotoxicol. Environ. Saf. 2018, 149, 128-134. [CrossRef]

6. Tao, Y.; Chen, Q.; Peng, S.; Wang, W.; Nie, L. Lower global warming potential and higher yield of wet direct-seeded rice in Central China. Agron. Sustain. Dev. 2016, 36, 24. [CrossRef]

7. Paman, U.; Inaba, S.; Uchida, S. The mechanization of small-scale rice farming: Labor requirements and costs. Eng. Agric. Environ. Food 2014, 7, 122-126. [CrossRef]

8. Hu, Y.J.; Xing, Z.P.; Gong, J.L.; Liu, G.T.; Zhang, H.C.; Dai, Q.G.; Huo, Z.Y.; Xu, K.; Wei, H.Y.; Guo, B.W.; et al. Study on population characteristics and formation mechanisms for high yield of pot-seedling mechanical transplanting rice. Sci. Agri. Sin. 2014, 47, 865-879.

9. Jiang, X.; Li, X.; Chi, Z.; Wang, S.; Yang, F.; Zheng, J. Research on potted-tray grown rice seedling transplanting by machine. Agri. Sci. Tech. 2014, 15, 1923-1927. 
10. Zhu, C.; Yang, H.J.; Guan, Y.X.; Chen, Z. Research progress on green and high efficiency cultivation technique of rice pot seedling mechanical transplanting in Jiangsu province. China Rice 2019, 25, 37-41.

11. Gaihre, Y.K.; Singh, U.; Islam, S.M.; Huda, A.; Satter, M.A.; Sanabria, J.; Islam, R.; Shah, A. Impacts of urea deep placement on nitrous oxide and nitric oxide emissions from rice fields in Bangladesh. Geoderma 2015, 260, 370-379. [CrossRef]

12. Watanabe, T.; Son, T.T.; Hung, N.N.; Van Truong, N.; Giau, T.Q.; Hayashi, K.; Ito, O. Measurement of ammonia volatilization from flooded paddy fields in Vietnam. Soil Sci. Plant Nutr. 2009, 55, 793-799. [CrossRef]

13. Yao, Y.; Zhang, M.; Tian, Y.; Zhao, M.; Zhang, B.; Zhao, M.; Zeng, K.; Yin, B. Urea deep placement for minimizing NH3 loss in an intensive rice cropping system. Field Crop. Res. 2018, 218, 254-266. [CrossRef]

14. Du, B.; Luo, H.W.; He, L.X.; Zheng, A.X.; Chen, Y.L.; Zhang, T.T.; Wang, Z.M.; Hu, L.; Tang, X.R. DEEP FERTILIZER PLACEMENT IMPROVES RICE GROWTH AND YIELD IN ZERO TILLAGE. Appl. Ecol. Environ. Res. 2018, 16, 8045-8054. [CrossRef]

15. Zhu, C.; Xiang, J.; Zhang, Y.; Zhang, Y.; Defeng, Z.; Chen, H. Mechanized transplanting with side deep fertilization increases yield and nitrogen use efficiency of rice in Eastern China. Sci. Rep. 2019, 9, 5653. [CrossRef]

16. Guo, L.; Ning, T.; Nie, L.; Li, Z.; Lal, R. Interaction of deep placed controlled-release urea and water retention agent on nitrogen and water use and maize yield. Eur. J. Agron. 2016, 75, 118-129. [CrossRef]

17. Li, X.; Chen, X.; Wang, H.; Lu, D.; Zhou, J.; Chen, Z.; Zhu, D. Effects and principle of root-zone one-time N fertilization on enhancing rice (Oryza sativa L.) N use efficiency. Soils 2017, 49, 868-875.

18. Wu, M.; Liu, M.; Liu, J.; Li, W.; Jiang, C.-Y.; Li, Z.-P. Optimize nitrogen fertilization location in root-growing zone to increase grain yield and nitrogen use efficiency of transplanted rice in subtropical China. J. Integr. Agric. 2017, 16, 2073-2081. [CrossRef]

19. Linquist, B.A.; Adviento-Borbe, M.A.; Pittelkow, C.M.; Van Kessel, C.; Van Groenigen, K.J. Fertilizer management practices and greenhouse gas emissions from rice systems: A quantitative review and analysis. Field Crop. Res. 2012, 135, 10-21. [CrossRef]

20. Yao, Z.; Zheng, X.; Zhang, Y.; Liu, C.; Wang, R.; Lin, S.; Zuo, Q.; Butterbach-Bahl, K. Urea deep placement reduces yield-scaled greenhouse gas $(\mathrm{CH} 4$ and $\mathrm{N} 2 \mathrm{O})$ and $\mathrm{NO}$ emissions from a ground cover rice production system. Sci. Rep. 2017, 7, 11415. [CrossRef]

21. Pan, S.; Wen, X.; Wang, Z.; Ashraf, U.; Tian, H.; Duan, M.; Mo, Z.; Fan, P.; Tang, X. Benefits of mechanized deep placement of nitrogen fertilizer in direct-seeded rice in South China. Field Crop. Res. 2017, 203, 139-149. [CrossRef]

22. Xu, Y.L.; Fu, A.B.; Liu, T.X. Effects of different nitrogen application patterns on leaf physiological characteristics and grain yield of double cropping rice. Acta Agric. Bor. Sin. 2019, 34, 155-163.

23. Shu, S.; Tang, X.R.; Luo, X.W.; Li, G.X.; Wang, Z.M.; Zheng, T.X.; Jia, X.N. Effects of deep mechanized application of slow-release fertilizers on physiological characteristics of precision hill-direct-seeding super rice. Trans. Chin. Soc. Agric. Eng. 2011, 27, 89-92.

24. Pan, S.; Rasul, F.; Li, W.; Tian, H.; Mo, Z.; Duan, M.; Tang, X. Roles of plant growth regulators on yield, grain qualities and antioxidant enzyme activities in super hybrid rice (Oryza sativa L.). Rice 2013, 6, 9. [CrossRef]

25. Plumb-Dhindsa, P.; Dhindsa, R.S.; Thorpe, T.A. Leaf Senescence: Correlated with Increased Levels of Membrane Permeability and Lipid Peroxidation, and Decreased Levels of Superoxide Dismutase and Catalase. J. Exp. Bot. 1981, 32, 93-101. [CrossRef]

26. Bandaogo, A.; Fofana, B.; Youl, S.; Safo, E.; Abaidoo, R.C.; Andrews, O. Effect of fertilizer deep placement with urea supergranule on nitrogen use efficiency of irrigated rice in Sourou Valley (Burkina Faso). Nutr. Cycl. Agroecosystems 2014, 102, 79-89. [CrossRef]

27. Kargbo, M.; Pan, S.; Mo, Z.; Wang, Z.; Luo, X.; Tian, H.; Hossain, F.; Ashraf, U.; Tang, X. Physiological Basis of Improved Performance of Super Rice (Oryza sativa) to Deep Placed Fertilizer with Precision Hill-drilling Machine. Int. J. Agric. Boil. 2016, 18, 797-804. [CrossRef]

28. Kapoor, V.; Singh, U.; Patil, S.K.; Magre, H.; Shrivastava, L.K.; Mishra, V.N.; Das, R.O.; Samadhiya, V.K.; Sanabria, J.; Diamond, R. Rice Growth, Grain Yield, and Floodwater Nutrient Dynamics as Affected by Nutrient Placement Method and Rate. Agron. J. 2008, 100, 526-536. [CrossRef]

29. Zhu, C.H.; Zhang, Y.P.; Xiang, J.; Zhang, Y.K.; Wu, H.; Wang, Y.L.; Zhu, D.F.; Chen, H.Z. Effects of side deep fertilization on yield formation and nitrogen utilization of mechanized transplanting rice. Sci. Agric. Sin. $2019,52,4228-4239$. 
30. Zhong, X.M.; Huang, T.P.; Peng, J.W.; Lu, W.L.; Kang, X.R.; Song, S.M.; Zhou, X. Effects of machine-transplanting synchronized with one-time precision fertilization on nutrient uptake and use efficiency of double cropping rice. Chin. J. Rice Sci. 2019, 33, 436-446.

31. Huda, A.; Gaihre, Y.K.; Islam, M.R.; Singh, U.; Islam, R.; Sanabria, J.; Satter, M.A.; Afroz, H.; Halder, A.; Jahiruddin, M. Floodwater ammonium, nitrogen use efficiency and rice yields with fertilizer deep placement and alternate wetting and drying under triple rice cropping systems. Nutr. Cycl. Agroecosystems 2016, 104, 53-66. [CrossRef]

32. Zhang, M.; Yao, Y.; Zhao, M.; Zhang, B.; Tian, Y.; Yin, B.; Zhu, Z. Integration of urea deep placement and organic addition for improving yield and soil properties and decreasing $\mathrm{N}$ loss in paddy field. Agric. Ecosyst. Environ. 2017, 247, 236-245. [CrossRef]

33. Danying, W.; Chang, Y.; Chunmei, X.; Zaiman, W.; Song, C.; Guang, C.; Zhang, X. Soil Nitrogen Distribution and Plant Nitrogen Utilization in Direct-Seeded Rice in Response to Deep Placement of Basal Fertilizer-Nitrogen. Rice Sci. 2019, 26, 404-415. [CrossRef]

34. Yao, Y.; Zhang, M.; Tian, Y.; Zhao, M.; Zhang, B.; Zeng, K.; Zhao, M.; Yin, B. Urea deep placement in combination with Azolla for reducing nitrogen loss and improving fertilizer nitrogen recovery in rice field. Field Crop. Res. 2018, 218, 141-149. [CrossRef]

35. Liu, T.; Fan, D.; Zhang, X.; Chen, J.; Li, C.; Cao, C. Deep placement of nitrogen fertilizers reduces ammonia volatilization and increases nitrogen utilization efficiency in no-tillage paddy fields in central China. Field Crop. Res. 2015, 184, 80-90. [CrossRef]

36. Zhou, J.; Meng, G.Y.; Long, J.R.; Ma, G.H.; Wan, Y.Z. Effects of application amount of slow-release nitrogen fertilizer on physiological characteristics and grain yield of early super hybrid rice zhuliangyou 02 . Hybrid Rice 2011, 26, 62-68.

37. Wang, Y.; Lin, A.; Loake, G.J.; Chu, C. H2O2?induced Leaf Cell Death and the Crosstalk of Reactive Nitric/Oxygen SpeciesF. J. Integr. Plant Boil. 2013, 55, 202-208. [CrossRef]

38. Tang, H.; Xiao, X.P.; Li, C.; Tang, W.G.; Guo, L.J.; Wang, K.; Cheng, K.; Pan, X.C.; Sun, G. Effects of different long-term fertilization managements on the physiological characteristics of leaves and yield of rice in double cropping paddy field. J. China Agric. Univ. 2018, 11, 60-71.

(C) 2020 by the authors. Licensee MDPI, Basel, Switzerland. This article is an open access article distributed under the terms and conditions of the Creative Commons Attribution (CC BY) license (http://creativecommons.org/licenses/by/4.0/). 